\title{
Unique coexpression in osteoblasts of broadly expressed genes accounts for the spatial restriction of ECM mineralization to bone
}

\author{
Monzur Murshed, ${ }^{1,2}$ Dympna Harmey, ${ }^{3}$ José Luis Millán, ${ }^{3}$ Marc D. McKee, ${ }^{4}$ and \\ Gerard Karsenty ${ }^{1,2,5}$ \\ ${ }^{1}$ Department of Molecular and Human Genetics, ${ }^{2}$ Bone Disease Program of Texas, Baylor College of Medicine, Houston, \\ Texas 77030, USA; ${ }^{3}$ The Burnham Institute, La Jolla, California 92037, USA; ${ }^{4}$ Faculty of Dentistry and Department of \\ Anatomy and Cell Biology, McGill University, Montreal, Quebec, Canada H3A 2B2
}

Extracellular matrix (ECM) mineralization is a physiological process in bone and a pathological one in soft tissues. The mechanisms determining the spatial restriction of ECM mineralization to bone physiologically are poorly understood. Here we show that a normal extracellular phosphate concentration is required for bone mineralization, while lowering this concentration prevents mineralization of any ECM. However, simply raising extracellular phosphate concentration is not sufficient to induce pathological mineralization, this is because of the presence in all ECMs of pyrophosphate, an inhibitor of mineralization. ECM mineralization occurs only in bone because of the exclusive coexpression in osteoblasts of Type I collagen and Tnap, an enzyme that cleaves pyrophosphate. This dual requirement explains why Tnap ectopic expression in cells producing fibrillar collagen is sufficient to induce pathological mineralization. This study reveals that coexpression in osteoblasts of otherwise broadly expressed genes is necessary and sufficient to induce bone mineralization and provides evidence that pathological mineralization can be prevented by modulating extracellular phosphate concentration.

[Keywords: ECM; mineralization; TNAP; pyrophosphate; collagen]

Supplemental material is available at http://www.genesdev.org.

Received October 25, 2004; revised version accepted March 14, 2005.

Extracellular matrix (ECM) mineralization is a physiological process in bones and teeth and, during skeletal growth, in growth plate cartilage. Anywhere else in the body, ECM mineralization is a pathological process. To date, the molecular mechanisms accounting for physiological ECM mineralization are not fully understood, and more importantly, we do not know how its spatial restriction to bone is achieved molecularly. These questions have important biomedical implications as diseases characterized by decreased bone mineralization, such as rickets and osteomalacia, are not infrequent (Wharton and Bishop 2003). Moreover, ectopic, i.e., pathological ECM mineralization in joints, as seen in osteoarthritis, is the most frequent degenerative condition of the skeleton and often has debilitating consequences (Hamerman 1989; Pay and Terkeltaub 2003). It is likely that the molecular mechanisms inducing ECM

${ }^{5}$ Corresponding author.

E-MAIL karsenty@bcm.tmc.edu; FAX (713) 798-1465.

Article published online ahead of print. Article and publication date are at http://www.genesdev.org/cgi/doi/10.1101/gad.1276205. mineralization are the same regardless of whether it is physiological, i.e., in bone, or pathological, i.e., ectopic. Thus, elucidating why ECM mineralization occurs only in bone may be important to ultimately achieve a better understanding of degenerative conditions such as osteoarthritis.

A widely accepted view is that the spatial restriction of ECM mineralization to bone is explained, at least in part, by osteoblast-specific gene products that initiate the formation of hydroxyapatite crystals $\left(\mathrm{Ca}_{10}\left[\mathrm{PO}_{4}\right]_{6}\right.$ $\left.[\mathrm{OH}]_{2}\right)($ Glimcher 1998). Hydroxyapatite is the predominant mineral crystal phase present in bone $\mathrm{ECM}_{\text {; }}$ it contains calcium $(\mathrm{Ca})$ and inorganic phosphate $\left(\mathrm{P}_{\mathrm{i}}\right)$ ions and is deposited both within and between collagen fibrils (Bachra and Fischer 1968). The requirement for genes expressed in osteoblasts to initiate the formation or control the growth of hydroxyapatite crystals is supported by the decrease in bone mineralization observed in mice and humans lacking either tissue-nonspecific alkaline phosphatase (TNAP) or PHEX, the protein mutated in X-linked hypophosphatemia (Eicher et al. 1976; Henthorn et al. 1992; Whyte 1994; The HYP Consortium 
1995; Waymire et al. 1995; Beck et al. 1997; Lipman et al. 1998; Fedde et al. 1999|. However, four observations challenge the view that osteoblast-specific genes explain the spatial restriction of ECM mineralization to bone. First, Tnap is not an osteoblast-specific or even a bonespecific gene; second, Phex deficiency affects profoundly the serum mineral ion balance, which in turn may affect ECM mineralization; third, deletion of osteoblastspecific genes long thought to play a role in bone mineralization did not affect this process (Aubin et al. 1995; Ducy et al. 1996); and fourth, ectopic ECM mineralization consisting of hydroxyapatite crystals occurs in the absence of osteoblasts in vivo (Luo et al. 1997). This latter observation established that in one instance ECM mineralization does not involve osteoblastspecific genes. It therefore raised the prospect that other mechanisms are involved to explain bone mineralization.

In contrast to the paucity of information explaining bone mineralization, genetic experiments have considerably improved our knowledge of the molecular mechanisms preventing ECM mineralization in soft tissues, i.e., ectopic ECM mineralization. This knowledge can contribute to our understanding of bone mineralization and may also lead to the prevention of pathological or ectopic ECM mineralization. Two types of genes are implicated in preventing ectopic ECM mineralization, some, like matrix gla protein $(M g p)$, which is expressed in vascular smooth muscle cells and chondrocytes and that encodes an extracellular mineral-binding protein, are not expressed in osteoblasts (Luo et al. 1997). A second class of ECM mineralization inhibitors includes genes such as Ank and Ectonucleotide pyrophosphatase/ phosphodiesterase 1 (Enpp1) that act by favoring secretion of pyrophosphate into the extracellular compartment (Okawa et al. 1998; Nakamura et al. 1999; Sali et al. 1999; Ho et al. 2000; Nurnberg et al. 2001). Inorganic pyrophosphate $\left(\mathrm{PP}_{\mathrm{i}}\right)$ is a small molecule made of two phosphate ions linked by an ester bond that binds to nascent hydroxyapatite crystals and prevents further incorporation of $\mathrm{P}_{\mathrm{i}}$ ions into these crystals (Fleisch and Bisaz 1962; Terkeltaub 2001). Unlike Mgp, Ank and Enpp1 are expressed in virtually every tissue and cell, including osteoblasts in bones, where they are expressed at their highest levels (Fig. 3A, below).

The secretion by osteoblast, the cell orchestrating bone mineralization, of an inhibitor of ECM mineralization like pyrophosphate is counter-intuitive. It suggests a model whereby the removal of an inhibitor rather than the synthesis of an inducer of mineralization would explain why ECM mineralization occurs in bone. Consistent with this model, we show here that removal of pyrophosphate and the presence of a fibrillar collagen-rich scaffold are two conditions necessary and sufficient to induce bone or ectopic ECM mineralization. Surprisingly, none of the genes involved in inducing ECM mineralization is osteoblast or even bone specific. However, osteoblast is the only cell type, along with odontoblasts and cementoblasts in teeth in which they are coexpressed.

\section{Results}

Extracellular $P_{i}$ concentration and induction of bone mineralization

The elucidation of the molecular bases of bone mineralization requires first to determine the role of each mineral ion involved. To achieve this goal, we focused our analyses on the respective roles of extracellular phosphate $\left(\mathrm{P}_{\mathrm{i}}\right)$ and $\mathrm{Ca}$ ion concentrations, as these two ions are the main mineral constituents of the hydroxyapatite crystal.

We first cultured mouse primary osteoblasts in the presence of various extracellular concentrations of $\mathrm{Ca}$ or $\mathrm{P}_{\mathrm{i}}$ and then assayed for ECM mineralization using von Kossa and Alizarin red staining. When primary mouse osteoblasts were cultured in the presence of $1.9 \mathrm{mM}$ extracellular Ca concentration but with increasing concentrations of extracellular $\mathrm{P}_{\mathrm{i}}$, the ECM surrounding these cells mineralized and there was formation of typical mineralized nodules (Fig. 1A; data not shown). In contrast, when osteoblasts were cultured in the presence of $1.2 \mathrm{mM}$ extracellular $\mathrm{P}_{\mathrm{i}}$ concentration but with increasing extracellular $\mathrm{Ca}$ concentrations, there was little evidence of ECM mineralization (Fig. 1B,C). This cell-based assay suggested that $P_{i}$ might be the prime mineral determinant of bone mineralization. To test this hypothesis in vivo, we used the Hyp mouse, a mutant mouse strain, characterized by an isolated decrease in extracellular phosphate concentration (hypophosphatemia) (Eicher et al. 1976; Beck et al. 1997). The main phenotypic abnormality accompanying hypophosphatemia in these mice is a decrease in bone mineralization (hyperosteoidosis). Phex, the gene mutated in Hyp mice, encodes an endopeptidase whose substrate is unknown. That a similar mutation in humans causes the disease called X-linked hypophosphatemic rickets underscores the biological importance of this regulatory loop (Lipman et al. 1998; Tenenhouse 1999). We reasoned that if extracellular $P_{i}$ concentration is the main ionic determinant triggering ECM mineralization in bone, then raising the serum $\mathrm{P}_{\mathrm{i}}$ level should correct the bone mineralization defect observed in $H y p$ mice.

Prior to testing this hypothesis, we asked whether the hyperosteoidosis of Hyp mice was due to an osteoblastautonomous defect. This is an important issue since conflicting data have been reported as to whether the defect in Hyp mice resides in osteoblasts (Meyer et al. 1989; Xiao et al. 1998) or not (Meyer et al. 1989; Xiao et al. 1998). To address this question directly, we cultured wild-type and Hyp osteoblasts in the presence of $5 \mathrm{mM} \mathrm{P}_{\mathrm{i}}$ in culture media. In this culture condition, Нyp osteoblasts became surrounded by a mineralized ECM at the same pace and to the same extent as wild-type osteoblasts (Fig. 1D). This result suggested that an intrinsic defect in Hyp osteoblasts, if it exists, is not sufficient to account for the hyperosteoidosis of Hyp mice. To verify that this was the case, we then fed Hyp mice a highphosphorus diet for $4 \mathrm{wk}$ and performed histological examination of vertebrae at the end of this 1-mo period. 


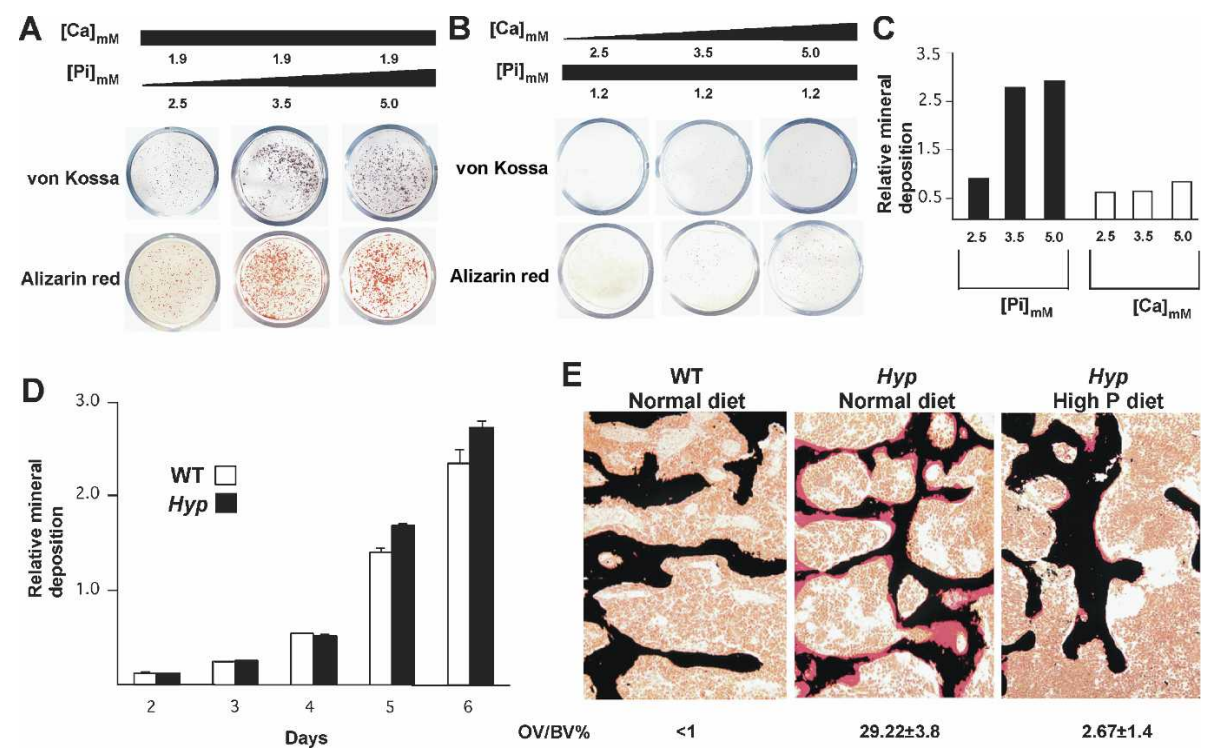

Figure 1. Role of mineral ions in inducing ECM mineralization. $(A-C)$ Extracellular mineral deposition as a function of $\mathrm{P}_{\mathrm{i}}$ concentration. Wild-type (WT) mouse osteoblasts were cultured in the presence of either constant extracellular Ca and increasing amount of $\mathrm{P}_{\mathrm{i}}\left(\mathrm{Na}_{2} \mathrm{HPO}_{4}\right)$, or constant $\mathrm{P}_{\mathrm{i}}$ and increasing amount of calcium $\left(\mathrm{CaCl}_{2}\right)$. As shown by von Kossa and Alizarin red staining, significant ECM mineralization occurred with increasing $P_{\mathrm{i}}$ concentration. $(D)$ In vitro mineralization of wild-type (WT) and $H y p$ osteoblasts. In the presence of $5 \mathrm{mM} \mathrm{P}_{\mathrm{i}}$ in culture media, ECM surrounding Hyp osteoblasts mineralized at the same pace and to the same extent as wild-type osteoblasts. (E) Von Kossa and van Gieson staining of vertebrae from 1-mo-old wild-type (WT) mice fed a normal diet and Hyp mice fed a normal or a high-phosphorus diet. Feeding of a high-phosphorus diet nearly normalized bone mineralization in Hyp mice $(n=6)$.

This analysis showed an almost complete rescue of the bone mineralization defect in Hyp mice as determined by the percentage of osteoid volume that remained unmineralized as shown by von Kossa staining (Fig. 1E). Biochemical analyses showed that this diet normalized the serum $\mathrm{P}_{\mathrm{i}}$ level without affecting the serum Ca level (Table 1). This near complete correction of the hyperosteoidosis phenotype of the Hyp mice by simply normalizing their extracellular $\mathrm{P}_{\mathrm{i}}$ concentration was in agreement with the notion suggested by the cell culture experiments that extracellular $\mathrm{P}_{\mathrm{i}}$ is a prime mineral determinant of bone mineralization.

\section{Extracellular $P_{i}$ concentration and ectopic ECM mineralization}

The important role of extracellular $\mathrm{P}_{\mathrm{i}}$ concentration as an initiator of bone mineralization demonstrated above suggested that decreasing the extracellular concentration of this mineral ion might be sufficient to prevent ectopic ECM mineralization. This was tested using two mutant mouse strains whose phenotypes bear similarities to human degenerative diseases characterized by ectopic ECM mineralization.

$\mathrm{Mgp}^{-/-}$mice are characterized by mineralization of

Table 1. Serum parameters

\begin{tabular}{|c|c|c|c|c|c|}
\hline Genotype & Diet & $\begin{array}{c}{\left[\mathrm{P}_{\mathrm{i}}\right] \mathrm{mg} / \mathrm{dL}} \\
( \pm \mathrm{SEM})\end{array}$ & $\begin{array}{c}{[\mathrm{Ca}] \mathrm{mg} / \mathrm{dL}} \\
( \pm \mathrm{SEM})\end{array}$ & $\begin{array}{c}{[\mathrm{PTH}] \mathrm{pg} / \mathrm{mL}} \\
( \pm \mathrm{SEM})\end{array}$ & $\begin{array}{c}{\left[1,25(\mathrm{OH})_{2} \mathrm{VitD}_{3}\right]} \\
\mathrm{pg} / \mathrm{mL}( \pm \mathrm{SEM})\end{array}$ \\
\hline WT & $\mathrm{N}$ & $8.08( \pm 0.63)$ & $9.87( \pm 0.95)$ & $59.09( \pm 4.66)$ & $49.00( \pm 4.00)$ \\
\hline WT & $\mathrm{HP}$ & $15.08( \pm 1.63)$ & $9.89( \pm 0.91)$ & $584.35( \pm 5.55)$ & $37.67( \pm 4.16)$ \\
\hline Нур & $\mathrm{N}$ & $3.98( \pm 0.22)$ & $9.84( \pm 0.60)$ & $90.59( \pm 8.39)$ & $41.67( \pm 3.51)$ \\
\hline Нур & $\mathrm{HP}$ & $7.88( \pm 0.27)$ & $10.00( \pm 0.39)$ & $136.90( \pm 10.19)$ & $41.67( \pm 7.77)$ \\
\hline$M g p^{-/-}$ & $\mathrm{N}$ & $8.22( \pm 0.19)$ & $9.58( \pm 0.39)$ & $96.7( \pm 8.39)$ & $44.33( \pm 3.21)$ \\
\hline$M g p^{-/-} ; H y p$ & $\mathrm{~N}$ & $4.17( \pm 0.41)$ & $9.47( \pm 0.33)$ & $97.27( \pm 6.38)$ & $43.67( \pm 9.07)$ \\
\hline$M g p^{-/-} ; H y p$ & $\mathrm{HP}$ & $7.66( \pm 0.87)$ & $9.37( \pm 0.44)$ & ND & ND \\
\hline ank & $\mathrm{N}$ & $7.64( \pm 0.83)$ & $9.98( \pm 0.32)$ & $64.27( \pm 3.00)$ & $43.00( \pm 1.73)$ \\
\hline ank & HP & $13.28( \pm 0.83)$ & $9.34( \pm 0.49)$ & $607.97( \pm 14.32)$ & $52.00( \pm 3.00)$ \\
\hline ank, Нyp & $\mathrm{N}$ & $4.17( \pm 0.41)$ & $9.47( \pm 0.95)$ & $92.5( \pm 43.98)$ & $60.33( \pm 4.93)$ \\
\hline ank, Нyp & $\mathrm{HP}$ & $8.07( \pm 0.63)$ & $9.85( \pm 0.21)$ & ND & ND \\
\hline Enpp $1^{-/-}$ & $\mathrm{HP}$ & $14.98( \pm 2.66)$ & $9.89( \pm 0.29)$ & $574.22( \pm 23.86)$ & $55.00( \pm 5.29)$ \\
\hline Tnap $^{-1-} ;$ ApoE-Tnap & $\mathrm{N}$ & $7.93( \pm 0.53)$ & $9.55( \pm 0.92)$ & $41.34( \pm 1.66)$ & $45.67( \pm 3.06)$ \\
\hline
\end{tabular}

(WT) Wild type; (N) normal diet; (HP) high-phosphorus diet; (ND) not determined. 
elastic and subsequently of collagen fibrils in all arteries, establishing that MGP is an inhibitor of ECM mineralization, at least in this tissue (Luo et al. 1997). MGP deficiency also causes ectopic ECM mineralization in humans, further underscoring the importance of this gene in the prevention of pathological ECM mineralization (Munroe et al. 1999). When placed on a Hyp genetic background, $\mathrm{Mgp}^{-/-}$mice never developed mineralization of their arterial ECM and, as a result, had a normal life span (Fig. 2A-C). All endocrine and metabolic parameters, besides the hypophosphatemia, were virtually identical in $\mathrm{Mgp}^{-/-}$and $\mathrm{Mgp}^{-/-}$; Hyp mice, thus these results suggest that lowering the extracellular $\mathrm{P}_{\mathrm{i}}$ level was sufficient to prevent ECM mineralization in arteries (Table 1). This notion was further confirmed by the fact that $\mathrm{Mgp}^{-/}$; Hyp mice fed a high-phosphorus diet had massive arterial ECM mineralization (Fig. 2C). In contrast, treatment of $\mathrm{Mgp}^{-/-}$mice with Foscarnet, an inhibitor of a sodium-phosphate cotransporter (Yusufi et al. 1986), from birth until $4 \mathrm{wk}$ of age failed to prevent arterial mineral deposition, suggesting that $P_{i}$ import into cells plays a less significant role than does the interaction of extracellular $\mathrm{P}_{\mathrm{i}}$ with matrix constituents in triggering ECM mineralization. Foscarnet treatment did not affect serum $P_{i}$ concentration (data not shown).

To further ascertain the role of extracellular $\mathrm{P}_{\mathrm{i}}$ during ECM mineralization, we asked whether decreasing its level could prevent ectopic ECM mineralization in another location and caused by another mechanism. Ank encodes a transmembrane protein required for extracellular export of the ECM mineralization inhibitor $\mathrm{PP}_{\mathrm{i}}$, a small molecule that inhibits ECM mineralization (Ho et al. 2000; Nurnberg et al. 2001; Terkeltaub 2001). Mice lacking Ank develop an osteoarthritis-like phenotype with deposition of hydroxyapatite crystals on articular surfaces, and $A N K$ gain of function mutations have been described in some osteoarthritic patients (Ho et al. 2000; Pendleton et al. 2002). As shown in Figure 2D and F, on a Hyp genetic background ank mice do not show any radiological or histological evidence of joint mineralization. Moreover, due to their increased mobility ank; Hyp mice had a normal life span, as opposed to ank mice, which usually die around 6 mo of age (Fig. 2E). Endocrine and metabolic parameters were comparable between ank; Hyp and Hyp mice (Table 1), suggesting that lowering serum phosphate level was sufficient to prevent the appearance of an osteoarthritis-like phenotype in these mice. As was the case with $\mathrm{Mgp}^{-{ }_{-}^{-}}$; Hyp mice, ank; Hyp mice fed a high-phosphorus diet developed joint ECM mineralization (Fig. 2F). By establishing the beneficial effect of lowering extracellular $\mathrm{P}_{\mathrm{i}}$ concentration to prevent ectopic ECM mineralization, these findings broadened the biological importance of extracellular $\mathrm{Pi}$ in the control of ECM mineralization.

An implication of the experiments presented so far is that if extracellular $\mathrm{P}_{\mathrm{i}}$ plays such a critical role in regulating ECM mineralization, then raising its extracellular concentration above physiological values should result in widespread ectopic ECM mineralization in wild-type mice.

To determine if this is the case, wild-type mice were fed from birth to 2 mo of age with a high-phosphorus diet. This resulted in a significant increase in serum $P_{i}$ concentration without affecting serum Ca concentration or any endocrine parameters except for an increase in serum parathyroid hormone (PTH) level (Table 1). However, and despite numerous attempts, this diet never led to histologically detectable ECM mineralization in any
Figure 2. Extracellular $P_{i}$ and ectopic ECM mineralization. (A) Alizarin red-stained skeletal preparation (thorax) of 1-mo-old wildtype (WT), $\mathrm{Mgp}^{-/-}$and $\mathrm{Mgp}^{-/-}$; Hyp mice. The arrow indicates mineralized aorta in $\mathrm{Mgp}^{-/-}$ mice. Note that unlike the $\mathrm{Mgp}^{-/-}$aorta, the aorta of a $\mathrm{Mgp}^{-/-}$; Hyp mouse did not mineralize. (B) $\mathrm{Mgp}^{-/-}$; Hyp mice had a normal life span $(n=10) .(C)$ Von Kossa staining of $\mathrm{Mgp}^{-/-}$; Hyp aorta sections showed no mineral deposition. Note extensive mineral deposition in arteries of 3-mo-old $\mathrm{Mgp}^{-1-}$; Hyp mice when fed a high-phosphorus diet. $(D) \mathrm{X}$ rays showing ectopic mineral deposition in joints of 4-mo-old ank mouse (arrow) but not in ank; Hyp mouse. (E) ank; Hyp mice had a normal life span $(n=8)$. $(F)$ Von Kossa and van Gieson staining of 3-mo-old wild-type (WT); ank and ank; Hyp joints. ank; Hyp mice fed a normal diet had no articular erosion. When fed a high-phosphorus diet ank; Hyp mice developed extensive joint mineralization.
A

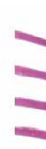

C
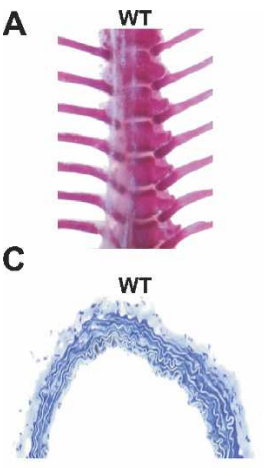

D

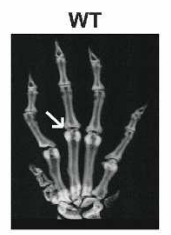

F

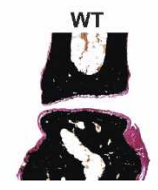

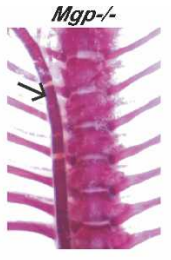

Mgp- -
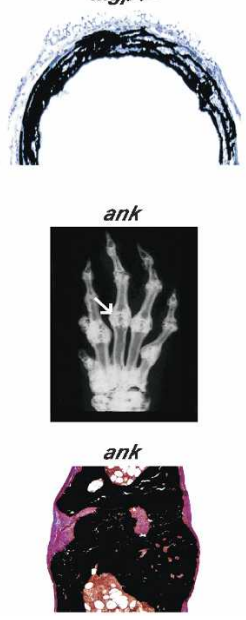
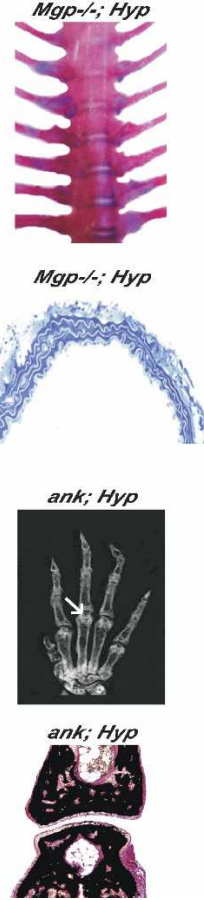

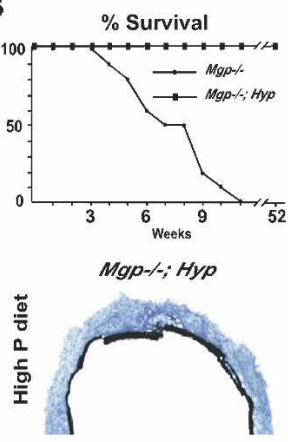

E
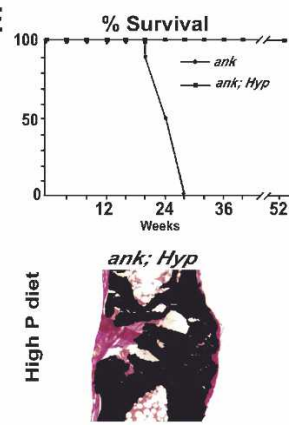
soft tissue analyzed (data not shown). We interpreted the failure of high extracellular $\mathrm{P}_{\mathrm{i}}$ concentration to induce pathological ECM mineralization in wild-type mice as an indication that, in all ECMs, mineralization is normally prevented by the existence of one or more inhibitors. That Ank and Enpp1, two genes required for the generation and transport in the extracellular milieu of $\mathrm{PP}_{\mathrm{i}}$, are broadly expressed (Fig. 3A) suggested that $\mathrm{PP}_{\mathrm{i}}$ might be this physiological inhibitor of ECM mineralization. If this is the case, raising serum $\mathrm{P}_{\mathrm{i}}$ level in ank or Enpp $1^{-/-}$mice should lead to pathological ECM mineralization.

To test this hypothesis, 3-wk-old ank or Enpp1 ${ }^{-/-}$mice were fed with the same high-phosphorus diet. As in wildtype mice, this diet resulted in an increase in serum $P_{i}$ and PTH levels (Table 1). After feeding these mutant mice for 2 wk with this high-phosphorus diet, the experiment had to be interrupted as the mobility of ank and Enpp $1^{-1-}$ mice was severely hampered. Histological examination revealed a major increase in joint mineralization of the 6-wk-old ank or Enpp1 $1^{-/-}$mice fed with this diet compared with their littermates fed a normal diet (Fig. 3B). This early deposition of mineral crystals in

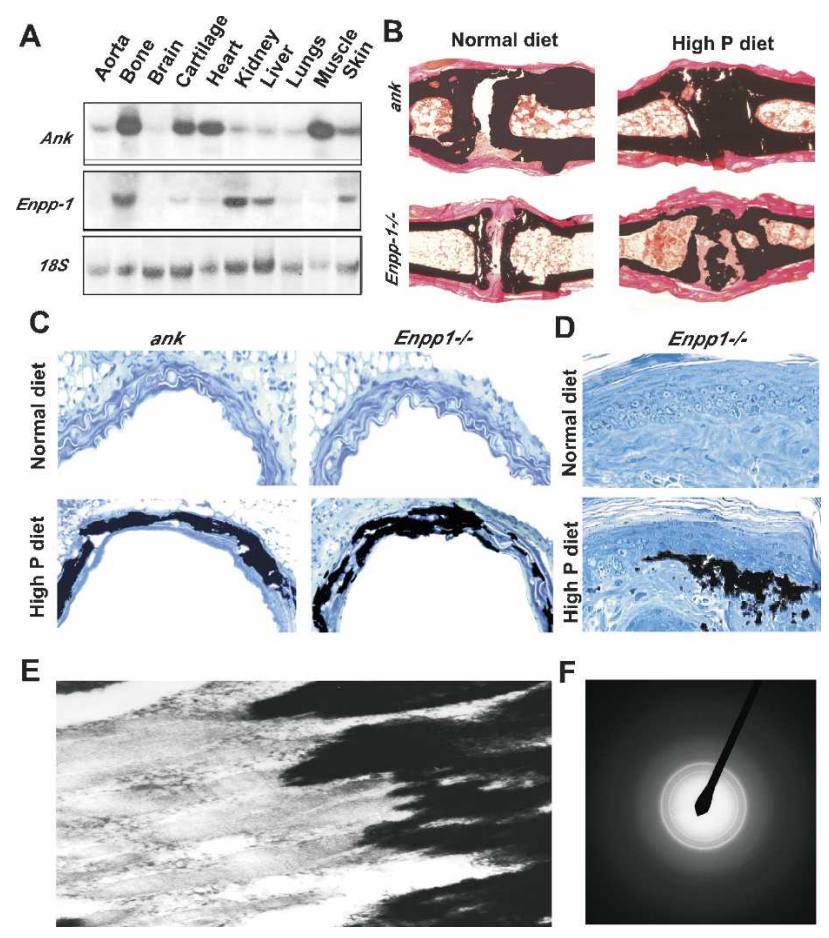

Figure 3. Pyrophosphate as a physiological inhibitor of ECM mineralization. (A) Northern blot. Ubiquitous expression of ank and Enpp1. $(B)$ Increasing serum $\mathrm{P}_{\mathrm{i}}$ level enhanced joint mineralization in 6-wk-old ank and Enpp1 $1^{-/-}$mice $(n=3)$. (C) Increased extracellular $\mathrm{P}_{\mathrm{i}}$ resulted in arterial ECM mineralization in 6-wk-old ank and Enpp 1-/- mice fed a high-phosphorus diet but not when fed a normal diet $(n=3)$. (D) ECM mineralization of dermis in 6-wk-old Enpp $1^{-/-}$mice fed a high-phosphorus diet but not when fed a normal diet. $(E)$ Transmission electron microscopy (TEM) showing deposition of mineral crystals along the collagen fibrils. $(F)$ Electron diffraction confirmed that the deposited mineral was hydroxyapatite. joints provided an explanation for the limited mobility of ank and Enpp1 $1^{-/-}$mice fed a high-phosphorus diet. We also observed mineralization of arteries and skin ECMs in these high-phosphorus-fed mutant mice (Fig. 3C,D). This mineralization was made of hydroxyapatite crystals deposited on collagen fibrils (Fig. 3E,F; data not shown).

Taken together, these experiments establish several points. First, the presence of $\mathrm{PP}_{\mathrm{i}}$ in all ECMs does prevent the occurrence of ectopic mineralization in wildtype mice. Second, raising extracellular $\mathrm{P}_{\mathrm{i}}$ concentration cannot induce ectopic ECM mineralization unless $\mathrm{PP}_{\mathrm{i}}$ is removed from the extracellular milieu. Third, PTH serum levels were similarly increased in wild-type, ank, and Enpp $1^{-/-}$mice fed with the high-phosphorus diet, yet only ank and Enpp $1^{-/-}$mice displayed ectopic ECM mineralization. This observation ruled out a major role for increased PTH level in preventing pathological ECM mineralization in high-phosphorus-diet-fed wild-type mice.

\section{Removal of pyrophosphate, a prerequisite to bone mineralization}

The results presented above highlight the importance of $\mathrm{P}_{\mathrm{i}}$ to induce ECM mineralization and of $\mathrm{PP}_{\mathrm{i}}$ as an inhibitor of ECM mineralization. How can we use this information to understand bone mineralization since Ank and Enpp1 are both expressed, at high levels, in osteoblasts (Fig. 3A; data not shown)? Thus a mechanism must exist to remove $\mathrm{PP}_{\mathrm{i}}$ from the bone ECM.

TNAP is a membrane-bound phospho-ester phosphatase present on the osteoblast surface whose inactivation leads to a major hyperosteoidosis phenotype in mice and humans (Henthorn et al. 1992; Whyte 1994; Waymire et al. 1995; Fedde et al. 1999). These observations suggest that TNAP might act as a pyrophosphatase in bone, although other pyrophosphatases may exist. Consistent with this contention, TNAP incubated in vitro with $\mathrm{PP}_{\mathrm{i}}$ had the ability to degrade it and thereby to produce $\mathrm{P}_{\mathrm{i}}$ (Supplementary Fig. 1; Eaton and Moss 1968). To determine the biological importance of TNAP ability to cleave $\mathrm{PP}_{\mathrm{i}}$ for bone mineralization, we cultured wildtype and Tnap ${ }^{-/-}$osteoblasts in the presence of $\mathrm{PP}_{\mathrm{i}}$, the proposed substrate of TNAP. As a positive control in this experiment, we cultured these cells in presence of $\beta$-glycerophosphate, the classical provider of $\mathrm{P}_{\mathrm{i}}$ ions (Ecarot-Charrier et al. 1983). In both culture conditions, the ECM surrounding wild-type osteoblasts mineralized while the ECM surrounding Tnap ${ }^{-1-}$ osteoblasts did not (Fig. 4A). Lastly, we cultured wild-type and Tnap ${ }^{-/}$ osteoblasts in the presence of $5 \mathrm{mM} \mathrm{P}_{\mathrm{i}}$. As expected in this culture condition Tnap ${ }^{-/-}$osteoblasts deposited minerals on the surrounding ECM albeit to a lesser extent than wild-type primary osteoblasts (Fig. 4A). These results indicate that TNAP's ability to cleave $\mathrm{PP}_{\mathrm{i}}$, which probably alters the $\mathrm{PP}_{\mathrm{i}}$ to $\mathrm{P}_{\mathrm{i}}$ ratio in the bone microenvironment, is a necessary requirement for bone mineralization. 
Figure 4. TNAP function and ECM mineralization. (A) Wild-type (WT) osteoblasts staining with Fast Blue confirming TNAP activity. ECM when culture media were supplemented either by $\beta$-glycerophosphate $(\beta \mathrm{GP})$ or $\mathrm{PP}_{\mathrm{i}}$. Tnap ${ }^{-/-}$osteoblasts did not stain blue and did not mineralize in either condition. When culture media were supplemented by $5 \mathrm{mM} \mathrm{P}_{\mathrm{i}}$, Tnap ${ }^{-/-}$ECM surrounding osteoblasts also mineralized albeit to a lesser extent than wild-type (WT) osteoblasts. $(B$, top) Transgene construct for liverspecific expression of Thap. (Bottom) Northern analysis using a $3^{\prime}$ probe specific for human Tnap cDNA showed liver-specific expression of the transgene. $(C)$ TNAP produced by the transgene was biologically active as it released phosphate from $\beta$ GP at a higher rate than the wild-type (WT) serum. (D) Increased TNAP serum concentration in ApoE-Tnap; Tnap ${ }^{-/}$mice prevented hyperosteoidosis caused by TNAP deficiency in Tnap $^{-/-}$mice $(n=3)$.
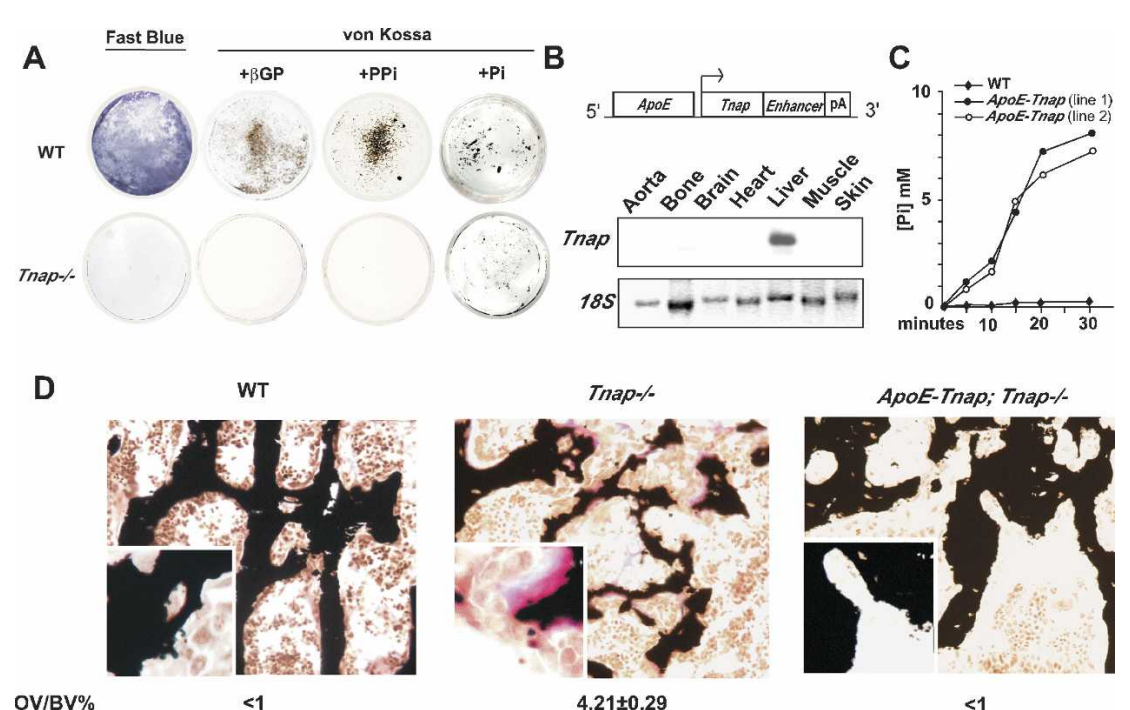

\section{A function for circulating TNAP during bone mineralization}

Two forms of TNAP exist; one membrane-bound and one circulating (Whyte 1994). Conceivably, the circulating form of TNAP could also affect bone mineralization. This is an important question since a poorly understood increase in serum TNAP level is a hallmark of rickets and osteomalacia, two diseases characterized by hyperosteoidosis (Reynolds et al. 1991).

To address this question, transgenic mice overexpressing Tnap under the control of the Apolipoprotein E promoter and a liver-specific enhancer were generated (Fig. 4B). These regulatory elements are active only after birth (Simonet et al. 1993). Two lines of ApoE-Tnap mice that had a $>10$-fold increase in their TNAP serum level were used for subsequent experiments. The fact that ApoETnap sera from both the lines released $\mathrm{P}_{\mathrm{i}}$ from $\beta$-glycerophosphate at a much higher rate than wild-type serum confirmed that the TNAP transcribed by the transgene was biologically active in each of the transgenic lines used (Fig. 4C). ApoE-Tnap mice had no metabolic abnormalities and no histological evidence of ectopic ECM mineralization (Table 1; data not shown). Of note, ApoETnap mice also had normal serum $\mathrm{P}_{\mathrm{i}}$ levels, suggesting that in this mouse model the pyrophosphatase activity of TNAP is not enough to markedly affect extracellular $P_{i}$ levels. Indeed, in a mouse model of hyperphosphatasia, the osteoprotegerin-deficient mouse, and in some hyperphosphatesia patients with very high serum TNAP levels, ectopic ECM mineralization does occur (Mitsudo 1971; Bucay et al. 1998).

We next asked whether this increase in TNAP activity could affect the severity of the hyperosteoidosis characterizing rickets and osteomalacia by transferring the ApoE-Tnap transgene on the Tnap ${ }^{-/-}$genetic background. Tnap ${ }^{-/-}$mice develop an hyperosteoidosis phe- notype and die at 2 wk of age (Waymire et al. 1995; Fedde et al. 1999). ApoE-Tnap; Tnap ${ }^{-1-}$ mice had a normal life span and none of the neurological manifestation observed in Tnap $^{-/-}$mice. Primary osteoblasts isolated from these mice did not stain for TNAP and did not mineralize in the presence of $\beta$-glycerophosphate (Supplementary Fig. 2). When bones of 1-mo-old ApoETnap; Tnap ${ }^{-1-}$ mice were analyzed histologically, we observed a complete rescue of the hyperosteoidosis characterizing Tnap ${ }^{-/-}$mice (Fig. 4D). These results indicate that while it does not always affect bone mineralization in wild-type mice, high Tnap expression in liver and/or high level of circulating TNAP can rescue an hyperosteoidosis. Indeed, the rescue of the osteoidosis by circulating TNAP suggests that it is explained in part by the high collagen content in the bone ECM, although other molecular events may contribute to it.

\section{Coexpression in osteoblasts of Thap and Type I collagen is necessary and sufficient for bone mineralization}

Thap is necessary for bone mineralization; however, this is most likely not sufficient for ECM mineralization, otherwise other organs expressing it such as liver and kidney would mineralize. The apparent contradiction between TNAP function that takes place in bone and Tnap expression that is not bone specific suggests that the spatial restriction of ECM mineralization to bone could be explained by a dual genetic requirement. In this model, coexpression in osteoblasts of Tnap and Type I collagen that would be necessary and sufficient to induce ECM mineralization in bone. This does not exclude that other pyrophosphatases besides TNAP expressed by osteoblasts could also contribute to bone mineralization. We favored Type I collagen as another necessary mol- 
ecule because mineralization occurs along collagen fibrils (Bachra and Fischer 1968; Glimcher 1998). The expression pattern of Tnap and Type I collagen is fully consistent with this model. Indeed, although Tnap, $\alpha 1(I)$ collagen, and $\alpha 2(I)$ collagen are expressed in several tissues, the only tissue in which they are coexpressed are bones and teeth, two mineralized tissues, where they are specifically coexpressed in osteoblasts and odontoblasts, respectively (Fig. 5A).

This model has two implications. The first one is that the extent of ECM mineralization should vary according to the ability of osteoblasts to synthesize Type I collagen. To test if this was the case, we used a rat osteoblastic cell line, the ROS 17/2.8 cells, mouse wild-type, and Atf $^{-/-}$osteoblasts. ATF4 is a transcription factor required for osteoblast differentiation and function that acts in part through favoring amino acid import (Harding et al. 2003). As a result Atf4 ${ }^{-/-}$osteoblasts have a major defect in Type I collagen synthesis (Yang et al. 2004). As previously shown, the ECM surrounding wild-type osteoblasts easily mineralized in the presence of $\mathrm{P}_{\mathrm{i}}$; in contrast, the ECM surrounding ROS 17/2.8 or Atf $4^{-/-}$osteoblasts never did (Fig. 5C). As shown in Figure 5B and C, the main feature shared by ROS $17 / 2.8$ and $A t f 4^{-/-}$osteoblasts is that they do not express or synthesize Type I collagen. This observation indicates that a fibrillar collagen network is necessary for ECM mineralization. To further demonstrate that it is the case, we reintroduced a
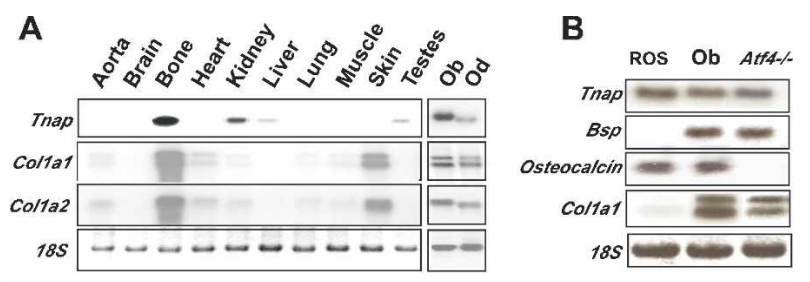

C
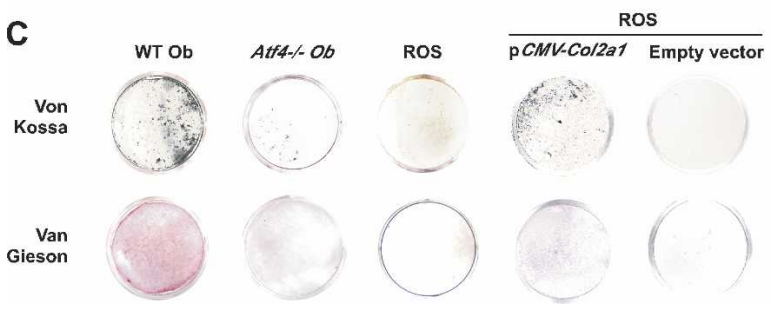

Figure 5. Type I collagen scaffold and ECM mineralization. (A) Northern blot showing coexpression of Thap, Col1a1, and Col1a2 only in skeletal tissues. (B) Northern blot analysis showing expression of osteoblast-specific genes in ROS 17/2.8 cells, primary osteoblasts $(\mathrm{Ob})$, and $A t f 4^{-/-}$cells. Expression of Col1a1 is markedly down-regulated in ROS $17 / 2.8$ cells. (C, top) Von Kossa staining showing a reduced mineralization of the ECM

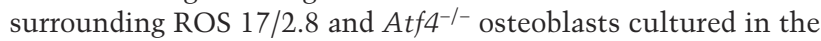
presence of $\beta$-glycerophosphate $(\beta \mathrm{GP})$ in comparison to wildtype (WT) osteoblasts. (Bottom) Van Gieson staining showed

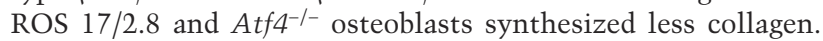
ROS 17/2.8 cells transfected with a Col2a1 expression vector produced a collagenous matrix (van Gieson staining) and mineralized when cultured in presence of $\beta$ GP. No ECM mineralization was seen in the case of empty vector transfected ROS cells. fibrillar collagen in ROS cells. ROS cells permanently transfected with a Col2a1 expression vector encoding Type II collagen and cultured in presence of $\beta$-glycerophosphate became surrounded by a mineralized ECM (Fig. 5C). Although necessary, a collagenous network alone is not sufficient to induce bone mineralization since the ECM surrounding Tnap ${ }^{-/}$osteoblasts, which is rich in Type I collagen, does not mineralize (Fig. 4A).

A second implication of this model is that ectopic expression of Tnap in Type I collagen-expressing cells should induce an ECM mineralization very similar to the one seen in bone, while ectopic expression of Tnap in mesenchymal cells that do not express fibrillar collagen genes should not. This hypothesis was tested in cell culture and in vivo. First, we ectopically expressed Tnap in NIH3T3 fibroblasts that express Type I collagen genes (Supplementary Fig. 3) but are not surrounded normally by a mineralized ECM. The TNAP activity of Tnap-expressing NIH3T3 cells was demonstrated by an enzymatic assay (Fig. 6A). Tnap-expressing NIH3T3 cells were then cultured in the presence of $\mathrm{PP}_{\mathrm{i}}$, the substrate of TNAP. In these culture conditions, the ECM surrounding the Tnap-expressing NIH3T3 cells always became mineralized, while the ECM surrounding NIH3T3 cells transfected with an empty vector never did (Fig. 6A). We also performed in vitro mineralization assay using mouse Hep1A hepatoma cells, which do not produce TNAP or Type I collagen (data not shown). That the ECM surrounding these cells mineralized in presence of $\beta$-glycerophosphate only when they were cotransfected with both Tnap- and Col2a1-expressing vectors demonstrated that synthesis of TNAP and a fibrillar collagen is necessary and sufficient to induce mineralization of multiple ECMs (Supplementary Fig. 4)

Next to test this hypothesis in vivo, we generated transgenic mice expressing Tnap in the dermis, a skin layer rich in Type I collagen, or in epidermis, a skin layer that does not contain fibrillar collagen (Fig. 6B). $\alpha 2(I)$ collagen-Tnap ( $\alpha 2(I)$-Tnap) transgenic mice expressed Tnap in skin fibroblasts and produced a functional TNAP as determined by Fast Blue staining (Fig. 6C; Niederreither et al. 1992; Bou-Gharios et al. 1996; Berton et al. 2000). This ectopic expression of Tnap was not associated with ectopic expression of osteoblast-specific noncollagenous proteins such as Osteocalcin and Bsp (data not shown). All $\alpha 2(I)-T n a p$ mice analyzed developed a dramatic mineralization of their skin ECM. This ECM mineralization consisted of hydroxyapatite crystals and occurred along collagen fibers, as is the case in bone (Fig. 6D-F; Supplementary Fig. 5A). In contrast, expression of Tnap in keratinocytes, a cell type that does not secrete fibrillar collagen, did not lead to mineralization of epidermis ECM (Fig. 6C-E). Further analysis of a2(I)-Tnap mice showed ECM mineralization in other locations such as arteries and sclera of the eye, two other tissues rich in Type I collagen and where the transgene was also expressed (Supplementary Fig. 5B). Taken together, these data are consistent with the hypothesis that the coexpression of genes, encoding pyrophosphatases, TNAP, and likely other ones, and fibrillar collagen 
Murshed et al.

A

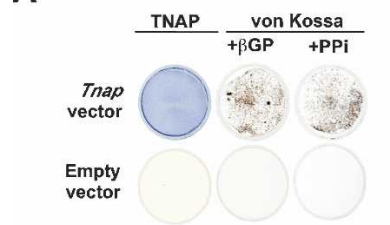

B

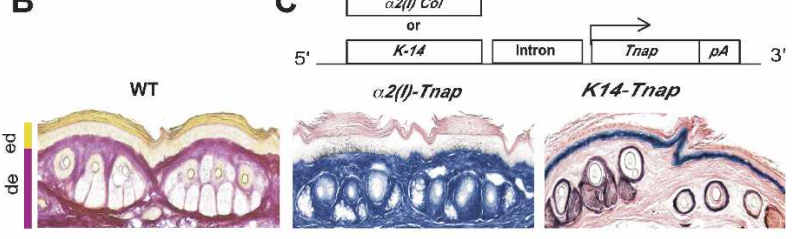

D

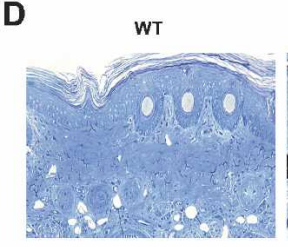

F

WT Skin

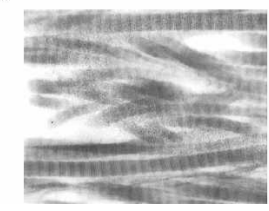

(21)-Tnap

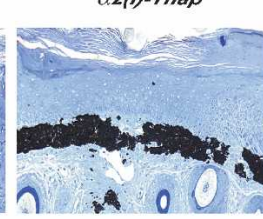

a2(I)-Tnap Skin

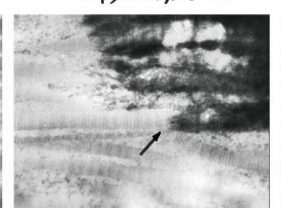

K14-Tnap

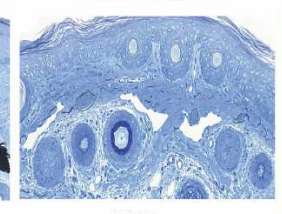

WT Bone

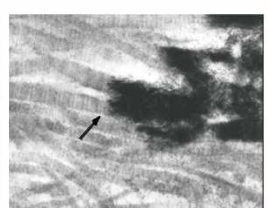

E wT a2(I)-Tnap א14-Tnap

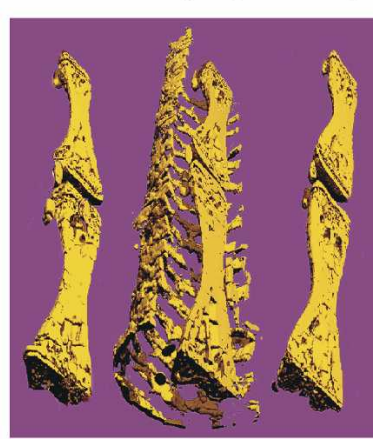

Figure 6. Coexpression of Tnap and Type I collagen is required for ECM mineralization. (A) NIH3T3 cells transfected with a Tnap expression vector produced TNAP as shown by Fast Blue staining. ECM surrounding these cells mineralized when cultured in presence of $\beta$-glycerophosphate $(\beta \mathrm{GP})$ or $\mathrm{PP}_{\mathrm{i}}$. No ECM mineralization was seen in the case of empty vector transfected NIH3T3 cells. $(B)$ Van Gieson staining (pink) of skin showing collagen in the dermis but not in the epidermis. (C,top) Transgene constructs for dermis- and epidermis-specific expression of Tnap. (Bottom) Fast Blue staining (blue) showing TNAP activity in the epidermis of K14-Tnap mice and dermis of $\alpha 2(I)$-Tnap mice. (D) Von Kossa staining showing massive mineral deposition in dermis of $\alpha 2(I)$-Tnap mouse, while no mineral deposition was seen in the epidermis of K14-Tnap mouse $(n=6)$. (E, middle) Micro-CT analysis of the mineralized tail of a

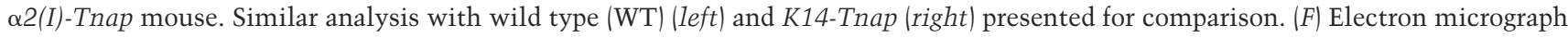
showing mineral deposition along collagen fibrils in the $\alpha 2(I)$-Tnap mouse.

is necessary and sufficient to induce ECM mineralization in bone and other tissues.

\section{Discussion}

Here we show that bone mineralization is determined partly by the ability of osteoblasts to remove a physiological inhibitor of mineralization pyrophosphate, from their surrounding ECM, and by the presence of a fibrillar collagen-rich network in the bone ECM. Remarkably, none of the genes identified so far and involved in the initiation of bone mineralization are osteoblast specific or even bone specific. The importance of these findings is underscored by the fact that coexpression of these genes in nonmesenchymal cells, i.e., liver cells, induces ectopic ECM mineralization. This study also demonstrates that by affecting the extracellular $\mathrm{P}_{\mathrm{i}} / \mathrm{PP}_{\mathrm{i}}$ ratio, it is possible to correct hyperosteoidosis as well as to prevent, in mice, pathological ECM mineralization similar to the one observed in human diseases.

\section{Mineral regulation of bone mineralization}

It has been shown $\sim 20$ years ago that normalizing $\mathrm{Ca}$ and $\mathrm{P}_{\mathrm{i}}$ concentrations correct the hyperosteoidosis of ricket patients (Balsan et al. 1986). This study, however, did not address the respective role of $\mathrm{Ca}$ and $\mathrm{P}_{\mathrm{i}}$ ions. That extracellular Ca concentration is more tightly regulated than extracellular $\mathrm{P}_{\mathrm{i}}$ concentration suggests that of these two ions, $\mathrm{P}_{\mathrm{i}}$ may be the critical element in the induction of mineral crystals in a given ECM (Potts and Juppner 1998). Consistent with this hypothesis, we present here cell-based and in vivo evidence demonstrating the crucial role played by extracellular $\mathrm{P}_{\mathrm{i}}$ during ECM mineralization. First, increasing $\mathrm{P}_{\mathrm{i}}$ concentration in cultured cells favors ECM mineralization, and second, correcting low serum $\mathrm{P}_{\mathrm{i}}$ concentration corrects a bone mineralization defect. These findings obtained in vivo are consistent with a model proposed recently (Giachelli 2003).

The mineralizing role of serum $\mathrm{P}_{\mathrm{i}}$ concentration is antagonized by another phosphate-derived molecule, pyrophosphate $\left(\mathrm{PP}_{\mathrm{i}}\right)$, whose presence prevents ectopic ECM mineralization in wild-type animals (Fleisch and Bisaz 1962; Terkeltaub 2001). The presence of $\mathrm{PP}_{\mathrm{i}}$ in almost every ECM explains why raising extracellular $\mathrm{P}_{\mathrm{i}}$ concentration does not result in pathological ECM mineralization in wild-type mice or in young $\mathrm{Fgf23}^{-/-}$mice (Sitara et al. 2004). That this potent inhibitor of ECM mineralization is a phosphate derivative and acts by preventing incorporation of $\mathrm{P}_{\mathrm{i}}$ in the nascent hydroxyapatite crystals is another line of evidence indicating that among all mineral ions, $\mathrm{P}_{\mathrm{i}}$ plays the most important role in triggering bone ECM mineralization. That serum $\mathrm{P}_{\mathrm{i}}$ level is not increased in ApoE-Tnap mice, which have high level of TNAP in serum, suggests TNAP main function during ECM mineralization is to remove an inhibitor, i.e., pyrophosphate rather than to regulate extracellular $\mathrm{P}_{\mathrm{i}}$ concentration. This observation strongly suggests that what 
triggers bone ECM mineralization is the ratio of $\mathrm{P}_{\mathrm{i}}$ to $\mathrm{PP}_{\mathrm{i}}$ a ratio determined to a large extent by TNAP function. The notion that the $\mathrm{P}_{\mathrm{i}}$ to $\mathrm{PP}_{\mathrm{i}}$ ratio is important to induce bone mineralization is in agreement with the observation that Tnap ${ }^{-/-}$mice that have abnormally high extracellular $\mathrm{PP}_{\mathrm{i}}$ level have hyperosteoidosis, while Tnap ${ }^{-/}$; Enpp1 ${ }^{-/-}$and Tnap ${ }^{-/}$; ank mice have a normal mineralization of the skull and normal extracellular $\mathrm{PP}_{\mathrm{i}}$ concentration (Hessle et al. 2002; Harmey et al. 2004). These findings provide also an explanation for the appearance of some pathological ECM mineralizations since coexpression in liver cells of Thap and Col2a1 induced ECM mineralization.

While we cannot dismiss at the present time the possibility that extracellular $\mathrm{Ca}$ concentration may also play an important role in the regulation of bone ECM mineralization, this is difficult to assess since, unlike for extracellular phosphate, there are no available animal models characterized by an isolated low extracellular $\mathrm{Ca}$ concentration. Indeed all mouse models with low extracellular Ca have also either low or high serum Pi level (Li et al. 1997; Gunther et al. 2000).

\section{Genetic regulation of bone mineralization}

Since at least one pyrophosphatase Tnap is not expressed only in osteoblasts, what are the genetic mechanisms accounting for the spatial restriction of ECM mineralization to bone? Two possible models have been proposed to answer this question. The first one would postulate that some gene products, presumably osteoblastspecific, would be responsible for the initiation of ECM mineralization in bone. The presence in the bone ECM of multiple phosphoproteins and mineral-binding proteins, some of them being encoded by osteoblast-specific genes, supports this hypothesis. However, mutant mouse strains in which some of these genes have been mutated do not have an overt bone mineralization defect (Aubin et al. 1995; Ducy et al. 1996). These results, however, do not definitely dismiss this hypothesis since not all genes encoding phosphoproteins have been deleted, and mutant mouse strains lacking several of these genes have not been generated or analyzed. The second mechanism hypothesizes that ECM mineralization is a passive process that is inhibited everywhere in the body but in bone. The existence of a mouse model in which deletion of a mineral-binding protein not produced in osteoblasts, MGP, leads to pathological or ectopic ECM mineralization supports this model (Luo et al. 1997). However, other models of ectopic ECM mineralization such as the ank or Enpp $1^{-/-}$mice are caused by mutations in genes encoding inhibitors of ECM mineralization expressed in osteoblasts and thereby challenge this view (Nakamura et al. 1999; Ho et al. 2000).

The lack of unambiguous evidence in support of one or the other models led us to test a third explanation hypothesizing that the spatial restriction of ECM mineralization to bone could be explained by the relief of an inhibition and the presence of a particular set of genes in osteoblasts. Again, the absolute requirement for the re- lief of an inhibition is illustrated by the secretion by osteoblasts of pyrophosphate, a potent physiological inhibitor of mineralization.

Evidence presented in this study supports this later model as an explanation of the spatial restriction of ECM mineralization to bone. Two types of genes are necessary and sufficient to trigger ECM mineralization. One, exemplified by Tnap, encodes a pyrophosphatase and therefore relieves an inhibition; another type of gene encodes fibrillar collagen and serves as a scaffold on which deposition occurs. This model borrows elements from the two previous models in the sense that, on the one hand, there is a need to relieve an inhibition, and on the other hand, there is a need for expression of a specific set of genes in osteoblasts. A surprising feature of these genes is that neither of them is osteoblast-specific; however, osteoblasts in bone and odontoblasts in teeth are the only cell types in which they are coexpressed. That Tnap is coexpressed with another gene encoding a fibrillar collagen $\alpha 1(\mathrm{X})$ collagen in hypertrophic chondrocytes of the growth plate cartilage (Takeda et al. 2001) is not contradictory with this model. Indeed, hypertrophic chondrocytes also express $M g p$, a powerful inhibitor of ECM mineralization (Luo et al. 1997).

\section{Local and systemic regulation of bone mineralization}

Is physiological ECM mineralization regulated locally only and/or systemically? This question is raised by two observations: First, lowering extracellular serum phosphate concentration leads to hyperosteoidosis, and second, some of the proteins involved in regulating ECM mineralization such as TNAP are circulating. We show here that increasing the serum concentration of circulating TNAP cannot induce ectopic ECM mineralization. This latter result indicates that only membranebound TNAP plays a physiological role during bone mineralization. It is known that circulating TNAP is elevated in some bone diseases (Reynolds et al. 1991). Our experiments indicate that the failure of past attempts to correct hyperosteoidosis in humans with TNAP may be explained by the fact that a continuous delivery of high dose of TNAP is needed (Whyte et al. 1984).

Is the role of extracellular phosphate and of TNAP conserved between mouse and humans? This is an important question given the potential therapeutic relevance demonstrated here of lowering extracellular phosphate concentration. The work of Balsan et al. (1986) along with human genetic diseases suggest that it is the case. Inactivation of Tnap in humans results in severe hyperosteoidosis, as in mice (Henthorn et al. 1992), Likewise, mutations in PHEX result in the same phenotypic consequences in human and mouse (Eicher et al. 1976; The Hyp Consortium 1995). This conservation of mechanisms raises the prospect that the management of ectopic ECM mineralization in humans could benefit from these findings. 


\section{Materials and methods}

\section{Mutant mice generation}

Generation of $\mathrm{Mgp}^{-/-}$, Tnap ${ }^{-/-}$, and Enpp1 $1^{-/-}$mice has been described (Luo et al. 1997; Waymire et al. 1995; Sali et al. 1999). Hyp and ank mice were obtained from the Jackson Laboratory. Hyp mice were on C57/BL6 background, while ank mice were on C3FeB6 background. pa2(I)-Tnap and pK14-Tnap constructs were generated by subcloning a human rabbit $\beta$-globin intronTnap cDNA cassette downstream of a dermis-specific $\alpha 2$ (I) Collagen promoter-enhancer fragment (Bou-Gharios et al. 1996) or a K14 promoter fragment (Berton et al. 2000), respectively. pApoE-Tnap was generated by inserting the Tnap cDNA in between a 3-kb ApoE promoter fragment and a liver-specific enhancer (Simonet et al. 1993). Transgenic founders were generated by standard techniques. Genotypes were determined by PCR using isolated tail DNA (primer sequences available upon request). For analysis of transgene expression, RNA was isolated and analyzed by Northern blotting using human Tnap cDNA as a probe (Ausubel et al. 1999).

\section{Skeletal preparation and histological analysis}

Thoracic aorta together with vertebrae were dissected, fixed overnight in $100 \%$ ethanol, and then stained in Alcian blue dye followed by Alizarin red solution as described (Luo et al. 1997). Vertebrae were fixed overnight in $4 \%$ paraformaldehyde/PBS, embedded in methyl methacrylate, sectioned $(7 \mu \mathrm{m})$ and stained by von Kossa and van Gieson. Unmineralized bone was measured using Osteomeasure software (Osteometrics Inc.). Aortas were fixed in $1 \%$ glutaraldehyde overnight, washed in $0.1 \mathrm{M}$ sodium cacodylate buffer, serially dehydrated in ethanol, and embedded in paraffin. Seven-micron sections were stained by von Kossa and counterstained by Toluidine blue. Cryosections of skin were stained with the von Kossa and/or van Gieson reagents. Alkaline phosphatase expression was detected with Fast Blue (Sigma). Images were captured with a light microscope (Leica, model DMLB) using a SPOT CCD camera, acquired with SPOT software v2.1 (Diagnostic Instruments, Inc.), and processed using Adobe Photoshop.

\section{Diet and serum parameters}

The high-phosphorus diet contained $2 \%$ phosphorus and $1.1 \%$ Ca or $2 \%$ phosphorus and $0.6 \%$ Ca (Harlan Teklad). The $2 \%$ phosphorus and $1.1 \%$ Ca diet was used to raise serum Pi level in Hyp mice. For all other experiments, 2\% phosphorus and $0.6 \%$ $\mathrm{Ca}$ diet was used. Serum Ca, phosphate, and alkaline phosphatase levels were measured using commercially available kits (Sigma). PTH concentration was measured using an ELISA kit for immunodetection (Immutopics). 1, 25-Dihydroxy vitamin D concentration was measured by a departmental core facility. Foscarnet $(100 \mu \mathrm{g} / \mathrm{kg} /$ day $)$ was injected subcutaneously from post-natal day $0(\mathrm{P} 0)$ to $\mathrm{P} 10$ and then intraperitoneally till mice were sacrificed.

\section{Cell culture and DNA transfection}

Primary osteoblast cultures from mouse calvaria and von Kossa staining for mineral deposition were performed as described previously (Ducy et al. 1999). For quantification of deposited minerals, mineralized cell layers were stained first with $40 \mathrm{mM}$ Alizarin red solution ( $\mathrm{pH} 4.0)$ for $5 \mathrm{~min}$ and then thoroughly washed in deionized water. Bound dye was dissolved in $10 \%$ glacial acetic acid and measured at $405 \mathrm{~nm}$ using a Bio-Rad microplate reader (model 550).
pEF-BOS-Tnap was constructed by inserting human Tnap cDNA into the mammalian expression vector $p E F-B O S$ (Mizushima and Nagata 1990). pCMV-Col2a1 construct was purchased from Invitrogen. Permanent transfections of NIH3T3 and ROS cells were performed using Lipofectamine (Invitrogen). Transfected cells were selected with $400 \mu \mathrm{g} / \mathrm{mL}$ G418, clones harvested individually and amplified under selection prior to analysis. TNAP synthesis was detected by fast blue staining. Hep1A cells were transiently transfected using Fugene (Roche) following suppliers instructions.

\section{Electron microscopy and mineral analysis}

Tissue samples were fixed in $0.1 \mathrm{M}$ sodium cacodylate (pH 7.3), $1 \%$ glutaraldehyde, and $4 \%$ paraformaldehyde; dehydrated to $100 \%$ ethanol; infiltrated with increasing concentrations of LR White acrylic resin (London Resin Company); and transferred to gelatin capsules for resin polymerization. Trimmed samples were viewed by light microscopy after von Kossa staining and then by transmission electron microscopy. Ultrastructural observations of collagen and mineral were recorded after staining of tissue sections with tannic acid and uranyl acetate, whereas selected-area electron diffraction for mineral identification was performed on unstained tissue sections. Data was obtained using a JEOL JEM-2000FX TEM equipped with a Gatan 792 Bioscan Multiscan CCD camera and conventional electron microscopy negatives. Imaging was done in the bright-field mode under Scherzer defocus conditions with the microscope operating at $80 \mathrm{kV}$. Selected-area electron diffraction was also performed at $80 \mathrm{kV}$. A synthetic hydroxyapatite was used as a standard reference for the TEM and SAED analyses.

\section{Acknowledgments}

We thank Dr. X. Yang for providing a northern membrane, Dr. D. Roop for the Keratin14 promoter, Dr. P. Ducy and R. Terkeltaub for critical reading of the manuscript, and L. Green and M. Starbuck for technical assistance. This study was supported by NIH grant PO1 AR42919, AR47908, and DE12889; MOD Foundation grant 1-FY99-489; and CIHR grant MT11360. M.M. was supported by a post-doctoral fellowship from American Heart Association (application ID 0325220Y).

\section{References}

Aubin, J.E., Gupta, A., Zirngibi, R., and Rossant, J. 1995. Bone sialoprotein knockout mice have bone abnormalities. Bone 17: 558 .

Ausubel, F.M., Brent, R., Kingston, R.E., Moore, D.D., Seidman, J.G., Smith, J.A., and Struhl, K. 1999. Current protocols in molecular biology. Wiley, New York.

Bachra, B.N. and Fischer, H.R. 1968. Recalcification of decalcified bone collagen in vitro as a model for biologic calcification. Calcif. Tissue Res. 2 Suppl: 7.

Balsan, S., Garabedian, M., Larchet, M., Gorski, A.M., Cournot, G., Tau, C., Bourdeau, A., Silve, C., and Ricour, C. 1986. Long-term nocturnal calcium infusions can cure rickets and promote normal mineralization in hereditary resistance to 1,25-dihydroxyvitamin D. J. Clin. Invest. 77: 1661-1667.

Beck, L., Soumounou, Y., Martel, J., Krishnamurthy, G., Gauthier, C., Goodyer, C.G., and Tenenhouse, H.S. 1997. Pex/PEX tissue distribution and evidence for a deletion in the $3^{\prime}$ region of the Pex gene in X-linked hypophosphatemic mice. J. Clin. Invest. 99: 1200-1209.

Berton, T.R., Wang, X.J., Zhou, Z., Kellendonk, C., Schutz, G., 
Tsai, S., and Roop, D.R. 2000. Characterization of an inducible, epidermal-specific knockout system: Differential expression of lacZ in different Cre reporter mouse strains. Genesis 26: $160-161$.

Bou-Gharios, G., Garrett, L.A., Rossert, J., Niederreither, K., Eberspaecher, H., Smith, C., Black, C., and Crombrugghe, B. 1996. A potent far-upstream enhancer in the mouse pro $\alpha 2(\mathrm{I})$ collagen gene regulates expression of reporter genes in transgenic mice. J. Cell. Biol. 134: 1333-1344.

Bucay, N., Sarosi, I., Dunstan, C.R., Morony, S., Tarpley, J., Capparelli, C., Scully, S., Tan, H.L., Xu, W., Lacey, D.L., et al. 1998. Osteoprotegerin-deficient mice develop early onset osteoporosis and arterial calcification. Genes \& Dev. 12: $1260-1268$.

Ducy, P., Desbois, C., Boyce, B., Pinero, G., Story, B., Dunstan, C., Smith, E., Bonadio, J., Goldstein, S., Gundberg, C., et al. 1996. Increased bone formation in osteocalcin-deficient mice. Nature 382: 448-452.

Ducy, P., Starbuck, M., Priemel, M., Shen, J., Pinero, G., Geoffroy, V., Amling, M., and Karsenty, G. 1999. A Cbfa1-dependent genetic pathway controls bone formation beyond embryonic development. Genes \& Dev. 13: 1025-1036.

Eaton, R.H. and Moss, D.W. 1968. Kinetic studies on the orthophosphatase and inorganic pyrophosphatase activities of human alkaline phosphatase. Enzymologia 35: 168-178.

Ecarot-Charrier, B., Glorieux, F.H., van der Rest, M., and Pereira, G. 1983. Osteoblasts isolated from mouse calvaria initiate matrix mineralization in culture. J. Cell. Biol. 96: 639-643.

Eicher, E.M., Southard, J.L., Scriver, C.R., and Glorieux, F.H. 1976. Hypophosphatemia: Mouse model for human familial hypophosphatemic (vitamin D-resistant) rickets. Proc. Natl. Acad. Sci. 73: 4667-4671.

Fedde, K.N., Blair, L., Silverstein, J., Coburn, S.P., Ryan, L.M., Weinstein, R.S., Waymire, K., Narisawa, S., Millan, J.L., MacGregor, G.R., et al. 1999. Alkaline phosphatase knockout mice recapitulate the metabolic and skeletal defects of infantile hypophosphatasia. J. Bone Miner. Res. 14: 20152026.

Fleisch, H. and Bisaz, S. 1962. Mechanism of calcification: Inhibitory role of pyrophosphate. Nature 195: 911.

Giachelli, C.M. 2003. Vascular calcification: In vitro evidence for the role of inorganic phosphate. I. Am. Soc. Nephrol. 14(Suppl 4): S300-S304.

Glimcher, M.J. 1998. The nature of mineral phase in bone, biological and clinical implications. In: Metabolic bone disease and clinically related disorders. (eds. L.V. Avioli and S.M. Krane), pp. 23-46. Academic Press, London, UK.

Gunther, T., Chen, Z.F., Kim, J., Priemel, M., Rueger, J.M., Amling, M., Moseley, J.M., Martin, T.J., Anderson, D.J., and Karsenty, G. 2000. Genetic ablation of parathyroid glands reveals another source of parathyroid hormone. Nature 406: 199-203.

Hamerman, D. 1989. The biology of osteoarthritis. N. Engl. J. Med. 320: 1322-1330.

Harding, H.P., Zhang, Y., Zeng, H., Novoa, I., Lu, P.D., Calfon, M., Sadri, N., Yun, C., Popko, B., Paules, R., et al. 2003. An integrated stress response regulates amino acid metabolism and resistance to oxidative stress. Mol. Cell 11: 619-633.

Harmey, D., Hessle, L., Narisawa, S., Johnson, K.A., Terkeltaub, R., and Millan, J.L. 2004. Concerted regulation of inorganic pyrophosphate and osteopontin by akp2, enpp1, and ank: An integrated model of the pathogenesis of mineralization disorders. Am. J. Pathol. 164: 1199-1209.

Henthorn, P.S., Raducha, M., Fedde, K.N., Lafferty, M.A., and Whyte, M.P. 1992. Different missense mutations at the tis- sue-nonspecific alkaline phosphatase gene locus in autosomal recessively inherited forms of mild and severe hypophosphatasia. Proc. Nat1. Acad. Sci. 89: 9924-9928.

Hessle, L., Johnson, K.A., Anderson, H.C., Narisawa, S., Sali, A., Goding, J.W., Terkeltaub, R., and Millan, J.L. 2002. Tissuenonspecific alkaline phosphatase and plasma cell membrane glycoprotein-1 are central antagonistic regulators of bone mineralization. Proc. Nat1. Acad. Sci. 99: 9445-9449.

Ho, A.M., Johnson, M.D., and Kingsley, D.M. 2000. Role of the mouse ank gene in control of tissue calcification and arthritis. Science 289: 265-270.

The HYP Consortium. 1995. A gene (PEX) with homologies to endopeptidases is mutated in patients with X-linked hypophosphatemic rickets. Nat. Genet. 11: 130-136.

Li, Y.C., Pirro, A.E., Amling, M., Delling, G., Baron, R., Bronson, R., and Demay, M.B. 1997. Targeted ablation of the vitamin $\mathrm{D}$ receptor: An animal model of vitamin D-dependent rickets type II with alopecia. Proc. Natl. Acad. Sci. 94: 98319835.

Lipman, M.L., Panda, D., Bennett, H.P., Henderson, J.E., Shane, E., Shen, Y., Goltzman, D., and Karaplis, A.C. 1998. Cloning of human PEX cDNA: Expression, subcellular localization, and endopeptidase activity. I. Biol. Chem. 273: 1372913737.

Luo, G., Ducy, P., McKee, M.D., Pinero, G.J., Loyer, E., Behringer, R.R., and Karsenty, G. 1997. Spontaneous calcification of arteries and cartilage in mice lacking matrix GLA protein. Nature 386: 78-81.

Meyer, R.A.J., Meyer, M.H., and Gray, R.W. 1989. Parabiosis suggests a humoral factor is involved in X-linked hypophosphatemia in mice. J. Bone Miner. Res. 4: 493-500.

Mitsudo, S.M. 1971. Chronic idiopathic hyperphosphatasia associated with pseudoxanthoma elasticum. J. Bone Joint Surg. Am. 53: 303-314.

Mizushima, S. and Nagata, S. 1990. pEF-BOS, a powerful mammalian expression vector. Nucleic Acids Res. 18: 5322.

Munroe, P.B., Olgunturk, R.O., Fryns, J.P., Van Maldergem, L., Ziereisen, F., Yuksel, B., Gardiner, R.M., and Chung, E. 1999. Mutations in the gene encoding the human matrix Gla protein cause Keutel syndrome. Nat. Genet. 21: 142-144.

Nakamura, I., Ikegawa, S., Okawa, A., Okuda, S., Koshizuka, Y., Kawaguchi, H., Nakamura, K., Koyama, T., Goto, S., Toguchida, J., et al. 1999. Association of the human NPPS gene with ossification of the posterior longitudinal ligament of the spine (OPLL). Hum. Genet. 104: 492-497.

Niederreither, K., D'Souza, R.N., and de Crombrugghe, B. 1992. Minimal DNA sequences that control the cell lineage-specific expression of the pro $\alpha 2(\mathrm{I})$ collagen promoter in transgenic mice. J. Cell. Biol. 119: 1361-1370.

Nurnberg, P., Thiele, H., Chandler, D., Hohne, W., Cunningham, M.L., Ritter, H., Leschik, G., Uhlmann, K., Mischung, C., Harrop, K., et al. 2001. Heterozygous mutations in ANKH, the human ortholog of the mouse progressive ankylosis gene, result in craniometaphyseal dysplasia. Nat. Genet. 28: 37-41.

Okawa, A., Nakamura, I., Goto, S., Moriya, H., Nakamura, Y., and Ikegawa, S. 1998. Mutation in Npps in a mouse model of ossification of the posterior longitudinal ligament of the spine. Nat. Genet. 19: 271-273.

Pay, S. and Terkeltaub, R. 2003. Calcium pyrophosphate dihydrate and hydroxyapatite crystal deposition in the joint: New developments relevant to the clinician. Curr. Rheumatol. Rep. 5: 235-243.

Pendleton, A., Johnson, M.D., Hughes, A., Gurley, K.A., Ho, A.M., Doherty, M., Dixey, J., Gillet, P., Loeuille, D., McGrath, R., et al. 2002. Mutations in ANKH cause chondro- 
Murshed et al.

calcinosis. Am. J. Hum. Genet. 71: 933-940.

Potts, J.J.T. and Juppner, H. 1998. Parathyroid hormone and Parathyroid hormone-related peptide in calcium homeostasis, bone metabolism, and bone development: The proteins, their genes and receptors. In Metabolic bone disease. (eds. L.V. Avioli and S.M. Krane), pp. 51-94. Academic Press Limited, London, UK.

Reynolds, R.D., Lorenc, R.S., Wieczorek, E., and Pronicka, E. 1991. Extremely low serum pyridoxal $5^{\prime}$-phosphate in children with familial hypophosphatemic rickets. Am. J. Clin. Nutr. 53: 698-701.

Sali, A., Favaloro, J.M., Terkeltaub, R., and Goding, J.W. 1999. Germline deletion of the nucleoside triphosphate pyrophosphohydrolase (NTPPPH) plasma cell membrane glycoprotein (PC-1) produces abnormal calcification of periarticular tissues. In Proceedings of the Second International Workshop on Ecto-ATPases and Related Ectonucleotidases. (eds. L. Vanduffel and R. Lemmens), pp. 267-282. Shaker Publishing BV, Maastricht, The Netherlands; Maastricht Shaker Publishing BV.

Simonet, W.S., Bucay, N., Lauer, S.J., and Taylor, J.M. 1993. A far-downstream hepatocyte-specific control region directs expression of the linked human apolipoprotein E and C-I genes in transgenic mice. J. Biol. Chem. 268: 8221-8229.

Sitara, D., Razzaque, M.S., Hesse, M., Yoganathan, S., Taguchi, T., Erben, R.G., Jüppner, H., and Lanske, B. 2004. Homozygous ablation of fibroblast growth factor- 23 results in hyperphosphatemia and impaired skeletogenesis, and reverses hypophosphatemia in Phex-deficient mice. Matrix Biol. 23: 421-432.

Takeda, S., Bonnamy, J.P., Owen, M.J., Ducy, P., and Karsenty, G. 2001. Continuous expression of Cbfal in nonhypertrophic chondrocytes uncovers its ability to induce hypertrophic chondrocyte differentiation and partially rescues Cbfa1deficient mice. Genes \& Dev. 15: 467-481.

Tenenhouse, H.S. 1999. X-linked hypophosphataemia: A homologous disorder in humans and mice. Nephrol. Dial. Transplant. 14: 333-341.

Terkeltaub, R.A. 2001. Inorganic pyrophosphate generation and disposition in pathophysiology. Am. J. Physiol. Cell Physiol. 281: $\mathrm{C} 1-\mathrm{C} 11$

Waymire, K.G., Mahuren, J.D., Jaje, J.M., Guilarte, T.R., Coburn, S.P., and MacGregor, G.R. 1995. Mice lacking tissue non-specific alkaline phosphatase die from seizures due to defective metabolism of vitamin B-6. Nat. Genet. 11: 45-51.

Wharton, B. and Bishop, N. 2003. Rickets. Lancet 362: 13891400.

Whyte, M.P. 1994. Hypophosphatasia and the role of alkaline phosphatase in skeletal mineralization. Endocr. Rev. 15: 439-461.

Whyte, M.P., McAlister, W.H., Patton, L.S., Magill, H.L., Fallon, M.D., Lorentz Jr., W.B., and Herrod, H.G. 1984. Enzyme replacement therapy for infantile hypophosphatasia attempted by intravenous infusions of alkaline phosphatase-rich Paget plasma: Results in three additional patients. I. Pediatr. 105: 926-933.

Xiao, Z.S., Crenshaw, M., Guo, R., Nesbitt, T., Drezner, M.K., and Quarles, L.D. 1998. Intrinsic mineralization defect in Hyp mouse osteoblasts. Am. J. Physiol. 275: E700-E708.

Yang, X., Matsuda, K., Bialek, P., Jacquot, S., Masuoka, H.C., Schinke, T., Li, L., Brancorsini, S., Sassone-Corsi, P., Townes, T.M., et al. 2004. ATF4 is a substrate of RSK2 and an essential regulator of osteoblast biology: Implication for Coffin-Lowry Syndrome. Cell 117: 387-398.

Yusufi, A.N., Szczepanska-Konkel, M., Kempson, S.A., McAteer, J.A., and Dousa, T.P. 1986. Inhibition of human renal epithelial $\mathrm{Na}+$ /Pi cotransport by phosphonoformic acid. Biochem. Biophys. Res. Commun. 139: 679-686. 


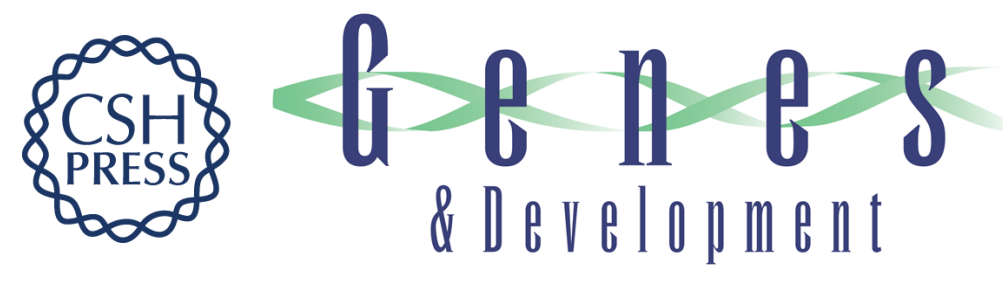

\section{Unique coexpression in osteoblasts of broadly expressed genes accounts for the spatial restriction of ECM mineralization to bone}

Monzur Murshed, Dympna Harmey, José Luis Millán, et al.

Genes Dev. 2005, 19:

Access the most recent version at doi:10.1101/gad.1276205

Supplemental http://genesdev.cshlp.org/content/suppl/2005/04/15/gad.1276205.DC1
Material

References This article cites 46 articles, 15 of which can be accessed free at:

http://genesdev.cshlp.org/content/19/9/1093.full.html\#ref-list-1

License

Email Alerting Receive free email alerts when new articles cite this article - sign up in the box at the top

Service right corner of the article or click here.

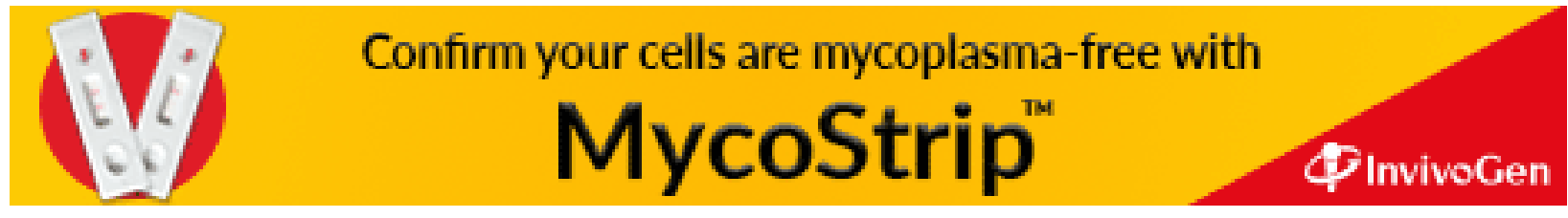

